\title{
Perfil das propriedades leiteiras em sistema de agricultura familiar na região norte do Paraná
}

Anelise de Mello Rubio, Daniel Sampaio Ferreira Lima, Gabriel Lourenzo, Jessica Quirino da Silva, Marcelo Alves da Silva”

Universidade Estadual do Norte do Paraná (UENP), Bandeirantes, PR, Brasil

*Autor correspondente

e-mail: masilva@uenp.edu.br

\section{Resumo}

No Brasil, em 2015, foram captados 24,5 bilhões de litros de leite e o Paraná ficou em terceiro lugar em produção de leite no país, com aproximadamente 13\% da produção nacional (IBGE, 2016). Bazotti et al. (2012) afirmaram que a quantidade de produtores que produzia até 50 litros de leite diária correspondia a $55,3 \%$ do total de produtores paranaenses (14,7\% da produção), enquanto os que produziam acima de 250 litros correspondiam a apenas $5,9 \%$ dos produtores (41,8\% da produção). 0 objetivo deste estudo foi avaliar, no ano de 2016, a produção e produtividade de 19 propriedades leiteiras provenientes de agricultura familiar em cinco municípios da região do Norte Pioneiro do Paraná e que já haviam sido assistidas por projetos de extensão da UENP. As propriedades foram divididas com base na produção diária de leite: até 100 litros, de 100 a 300 litros e acima de 300 litros. Com base na produtividade de leite/hectare/ano, foram divididas em: produtividade inferior a 5 mil litros, 5-10 mil litros e acima de 10 mil litros de leite/hectare/ ano. 0 rebanho total das 19 propriedades foi de 1.041 animais, com 349 vacas em lactação do total de 497 (33,52\% do rebanho em lactação ou 70,22 das vacas em lactação). A quantidade média de vacas por propriedade foi de 26,29 animais e 18,35 em lactação, obtendo uma produção média diária de 287 litros/ dia ( \pm 85,88 litros) com Coeficiente de Variação (CV) de 88,23\%, e produção diária por animal de 14,86 litros ( \pm 5,32 litros) e CV de 35,8 \%. Em relação à produção diária, seis propriedades apresentaram produção abaixo de 100 litros(31,58\%), sete apresentaram produção entre 100 e 300 litros (36,84\%) e seis propriedades apresentaram produção acima de 300 litros (31,58\%). Já a produtividade por hectare/ ano apresentou correlação negativa em relação ao tamanho da área, onde seis propriedades apresentaram produção inferior a 5 mil litros (31,58\%), com área média de 25,01 ha; seis propriedades apresentaram produção entre 5-10 mil litros (31,58\%), com área média de 15,5 ha; e sete propriedades apresentaram produção acima de 10 mil litros de leite/hectare/ano (36,84\%), com área média de 7,86 ha. Comparando 
estes resultados ao que o Fórum dos Promotores do Desenvolvimento do Agronegócio Paranaense de 2012 definiu como propriedade leiteira sustentável (produção diária de 300 litros e produtividade de 40 litros/ha/dia), somente duas das dezenove propriedades estariam adequadas, apesar de outras cinco apresentarem produção acima de 10 mil litros de leite/hectare/ano e outras quatro apresentarem produção diária acima de 300 litros dia. A partir dos resultados obtidos, independente do município, da produção diária e produtividade/ha/ano, existem propriedades em sistema de agricultura familiar com produção sustentável e propriedades passando por sérias dificuldades, possibilitando exemplos locais de bons e maus resultados. 